\title{
REKRUTMEN CALONANGGOTA DEWAN PERWAKILAN RAKYAT DAERAH (DPRD) OLEH PARTAI POLITIK PADA PEMILU LEGISLATIF
}

\author{
Mikael Mahin \\ Fakultas Ilmu Sosial Dan Ilmu Politik Universitas Kapuas Sintang \\ Jalan J.C Oevang Oeray Nomor 92 Sintang Kalimantan Barat \\ Email:mahinmikael@gmail.com
}

\begin{abstract}
Abstrak:Rekrutmen Calon Anggota DPRD Oleh DPD Partai Perindo Dalam Pemilihan Legislatif Di Kabupaten Sintang telah mengacu pada Petunjuk Pelaksanaan (Juklak) dan Petunjuk Teknis (Juknis) yang telah dibuat oleh Dewan Pimpinan Pusat Partai Perindo.Adapun tahapan Pencalonan adalah Pengambilan Formulir beserta syarat Pendaftaran Calon Legislatif, Penelitian Administrasi dan Kelengkapan Bacaleg, Pengumuman hasil administrasi dan Kelayakan Bacaleg, Uji Publik/Fit Profer Tes/Interview, Penyusunan Daftar Caleg Perindo, Pengumuman Caleg Perindo di Media Massa. Seleksi oleh Dewan Pimpinan Daerah Partai Perindo dengan cara membentuk Tim Rekrutmen dan Seleksi Caleg. Calon Anggota DPRD Kabupaten Sintang dari Partai Perindo yang lolos seleksi sebanyak 40 orang yang terdiri dari laki-laki 23 Orang sedangkan perempuan berjumlah 17 orang. Aspek Dalam Penyaringan Calon Anggota DPRD adalah memiliki pengabdian dan rekam jejak yang baik selama aktif di Partai Perindo; memiliki Prestasi, Dedikasi, Disiplin, Loyalitas dan tidak tercela; dan memenuhi ketentuan yang disyaratkan oleh Undang-Undang Pemilu. Dalam Pemilihan Calon Anggota DPRD dengan mempertimbangkan kemampuan Pembicara yang baik, mempunyai keahlian khusus, memiliki semangat dan antusias tinggi serta mempunyai pengetahuan yang dalam terhadap isu-isu politik. Komitmen pada Daerah Pemilihan, dukungan massa partai politik dan organisasi kemasyarakatan, Pengalaman politik dan pengalaman sebagai Pengurus partai.
\end{abstract}

Kata Kunci: Rekrutmen, Calon Anggota Legislatif, Pemilu Legislatif

Negara Indonesia adalah negara demokrasi. Salah satu ciri dari negara demokrasi adalah adanya pemilihan umum. Sebagaimana diungkapkan oleh Rudy (2007:87) bahwa "melalui pemilihan umum rakyat memilih wakilnya untuk duduk dalam parlemen dan dalam struktur pemerintahan". Artinya dengan pemilu masyarakat memberi mandat bagi parlemen dan pemerintah untuk mengurus negara. Hal ini sesuai dengan prinsip demokrasi "pemerintahan dari rakyat, oleh rakyat dan untuk rakyat".Pemilihan umum merupakan cara perekrutan anggota legislatif yang digunakan oleh sebagian besar negara di dunia, termasuk Indonesia. Rakyat, yang memiliki kedaulatan tertinggi dalam negara demokrasi, menyuarakan pilihannya melalui pemilihan umum untuk menentukan wakilnya yang duduk sebagai anggota dewan. Dalam konteks model politik Indonesia, pemilu merupakan suatu proses substitus kekuasaan.

Partai politik sebagai suatu organisasi sangat berperan dalam mencetak pemimpin yang berkualitas dan berwawasan nasional. Pemimpin yang berkualitas ini tidak hanya berorientasi pada kepentingan partai politik yang diwakili. Ketika menjadi pemimpin nasional, otomatis menjadi pemimpin semua orang. Pemimpin ini tidak lahir dengan sendirinya. Perlu suatu proses pendidikan baik yang bersifat formal maupun non-formal yang mampu membentuk jiwa dan karakter pemimpin. Dalam sttruktur dan sistem politik, organisasi partai politiklah yang paling bertanggung jawab untuk melahirkan pemimpin-pemimpin yang berkualitas. Untuk dapat melakukan tugas ini, dalam tubuh organisasi partai politik perlu dikembangkan sistem rekrutmen, seleksi, dan kaderisasi politik. Mendapatkan sumber daya yang baik perlu dimulai dari sistem rekrutmen. Dengan adanya sistem ini, nantinya akan dapat diseleksi kesesuaian antara karakteristik kandidat dengan sistem nilai dan ideologi partai politiknya. Tentunya orang-orang yang memiliki sistem nilai dan ideologi sama serta memiliki potensi untuk dikembangkanlah yang perlu direkrut. Persaingan dengan partai politik lain juga terjadi untuk memperebutkan orang-orang terbaik yang nantinya dapat memperkuat dan mengembangkan organisasi partai politiknya. Secara ideal partai politik harus melaksanakan fungsi rekrutmen politiknya dengan sugguhsungguh demi kepentingan rakyat dengan merekrut individu-individu yang memiliki kualitas, kapabilitas dan integritas yang baik. Partai politik harus melaksanakan rekrutmen yang terbuka dan demokratis. Tetapi dalam prakteknya model tertutup kerap kali dilakukan oleh partai politik. Hal ini menimbulkan kekhawatiran akan munculnya wakil rakyat yang tidak mampu memperjuangkan aspirasi yang diwakilinya. 
Fenomena asal calon yang dilakukan oleh partai politik terlihat dari maraknya partai politik merekrut figur-figur populer yang sebetulnya memiliki latar belakang yang sangat jauh dari dunia politik. Stigma negatif terhadap anggota legislatif diakibatkan oleh realitas ketidak puasan masyarakat terhadap kinerja anggota legislatif, berdasarkan survei lembaga survei nasional angka ketidak percayaan masyarkat terhadapa anggota legislatif sanggat tinggi. Berdasarkan asumsi masyarakat itu, maka timbulah pertanyaan bagi mana peran partai politik dalam menjaring calon anggota legislatif, karena dalam sitem politik demokrasi seperti indonesia peran partai politik sanggat berperan dalam mendukung supra struktur politik. Rekrutmen Calon Anggota DPRD Oleh DPD Partai Perindo Dalam Pemilihan Legislatif Di Kabupaten Sintang Partai Perindo menyeleksi bakal calon Anggota Legislatif (Caleg) yang akan diturunkan dalam pileg 2019. Perindo berusaha mendapatkan caleg yang berkompeten di masing-masing daerah pemilihan (dapil). Adapun model rekrutmen Calon Legislatif Partai Perindo dimulai dengan pembukaan pendaftaran online, offline, baru kemudian diwawancara.

Menurut Ramlan Surbakti, (1992:113) Partai politik dalam dunia perpolitikan, khususnya dalam politik lokal akan mudah dipahami dengan mengerti terlebih dahulu definisi partai politik. Ada tiga teori yang mencoba menjelaskan asal usul partai politik. Pertama, teori kelembagaan yang melihat ada hubungan antara parlemen awal dan timbulnya partai politik, kedua, teori situasi historic yang melihat timbulnya partai politik sebagai upaya suatu sistem politik untuk mengatasi krisis yang ditimbulkan dengan perubahan masyarakat secara luas. Ketiga, teori pembangunan yang melihat partai politik sebagai produk modernisasi sosial ekonomi. Partai politik pertama lahir di negara-negara Eropa Barat. Dengan meluasnya gagasan bahwa rakyat merupakan faktor yang perlu diperhitungkan serta diikutsertakan dalam proses politik, maka partaipartai politik telah lahir secara spontan dan berkembang menjadi penghubung antara rakyat dan pemerintah. Bambang Sunggono, (1992:7). Partai politik terlahir untuk mewujudkan suatu gagasan bahwa rakyat merupakan faktor yang perlu diikut sertakan dalam proses politik. Melalui partai politik inilah rakyat turut berpartisipasi dalam hal memperjuangkan dan menyalurkan aspirasiaspirasinya atau kepentingan-kepentingannya. Dengan demikian, proses artikulasi kepentingan tersalurkan melalui partai politik. Ramlan Surbakti (1992:116) menyatakan bahwa "partai politik merupakan sekelompok orang yang terorganisir secara rapi yang dipersatukan oleh persamaan ideologi yang bertujuan untuk mencari dan mempertahankan kekuasaan dalam pemilihan umum guna melaksanakan alternative kebijakan yang telah mereka susun". Alternatif kebijakan umum yang disusun ini merupakan hasil pemanduan berbagai kepentingan yang hidup dalam masyarakat, sedangkan cara mencari dan mempertahankan kekuasaan guna melaksanakan kebijakan umum dapat melalui pemilihan umum dan cara-cara lain yang sah.

Pendapat Miriam Budiardjo dalam A. Rahman H. I (2007:103-104) terkait fungsi partai politik yang melekat dalam suatu partai politik sebagai berikut: Komunikasi Politik, Komunikasi politik merupakan fungsi menyalurkan berbagai macam pendapat dan aspirasi masyarakat ditengah keberagaman pendapat masyarakat modern yang terus berkembang. Pendapat atau aspirasi seseorang atau suatu kelompok akan hilang tidak berbekas apabila tidak ditampung dan digabung dengan pendapat dan aspirasi orang lain yang senada, proses tersebut dinamakan (interest aggregation). Setelah penggabungan pendapat dan aspirasi tersebut diolah dan dirumuskan sedemikian rupa sehingga kesimpangsiuran pendapat dalam masyarakat berkurang (interest articulation). Jika peran utama ini tidak dilakukan pasti akan terjadi kesimpang siuran isu dan saling berbenturan. Sosialisasi Politik. Sosialisasi politik merupakan sebuah proses dimana seseorang memperoleh sikap dan orientasi terhadap fenomena politik yang umumnya berlaku dalam masyarakat dimana dia berada. Proses ini merupakan faktor penting dalam terbentuknya budaya politik (political culture) suatu bangsa karena proses penyampaiannya tersebut berupa norma-norma dan nilai-nilai dari suatu generasi ke generasi berikutnya. Rekrutmen Politik. Rekruitmen politik merupakan fungsi untuk mempersiapkan kepemimpinan internal maupun nasional karena setiap partai membutuhkan kader-kader yang berkualitas untuk dapat mengembangkan partainya. Rekrutmen politik menjamin kontinuitas dan kelestarian partai, sekaligus merupakan salah satu cara untuk menjaring dan melatih calon-calon pemimpin. Pengatur Konflik Politik. Pendatur konflik politik merupakan fungsi untuk membantu mengatasi konflik diantara masyarakat atau sekurang-kurangnya dapat diatur sedemikian rupa sehingga akibat negatifnya dapat ditekan seminimal mungkin.

Menurut Syamsuddin Haris (2005:8), Perekrutan anggota legislatif oleh partai politik secara umum mencakup tiga tahap penting yakni: Penjaringan calon, dimana dalam tahapan ini mencakup interaksi antara elite partai di tingkat des/kelurahan atau ranting partai dengan elite partai di tingkat atasnya atau anak cabang. Penyaringan dan seleksi calon yang telah dijaring. Tahapan ini meliputi interaksi antara elit tingkat anak cabang dan elite tingkat kabupaten/kota atau cabang/ daerah. Penetapan calon berikut nomor urutnya. Tahapan ini melibatkan interaksi antara elit tingkat cabang/daerah, terutama pengurus harian partai 
tingkat cabang/daerah dengan tim kecil yang dibentuk dan diberikan wewenang menetapkan calon legislatif. Model rekrutmen dan seleksi politik juga dijelaskan oleh Philip Althoff dan Michael Rush (2007:70). Keduanya membagi model rekrutmen dan seleksi politik kedalam tujuh model, yaitu: Seleksi melalui ujian dan pelatihan Model ini merupakan model yang umum digunakan, biasanya dilakukan untuk mengisi jabatan-jabatan birokrasi dan administrasi. Seleksi melalui penyortiran Model ini dilakukan dengan melakukan penyortiran atau penarikan undian. Model ini digunakan untuk memperkokoh kedudukan pemimpin politik. Seleksi melalui rotasi dan giliran Model ini dilakukan untuk mencegah dominasi jabatan dan posisi-posisi berkuasa oleh orang atau kelompok individu tertentu. Melalui perebutan kekuasaan Model ini biasanya digunakan dengan jalan menggunakan atau mengancamkan kekerasan. Melalui Patronage Model ini dilakukan dengan penyuapan dan korupsi. Model ini banyak digunakan oleh masyarakat Inggris. Seleksi dengan memunculkan pemimpin-pemimpin alamiah Model ini merupakan pembenaran kasar terhadap kekuasaan aristokrasi. Melalui Koopsi Model ini dilakukan dengan cara di mana pemimpin yang ada dapat membantu pelaksanaan perekrutan tipe-tipe pemimpin tertentu.

Dalam Peraturan Komisi Pemilihan Umum Republik Indonesia Nomor 20 Tahun 2018 tentang Pencalonan Anggota Dewan Perwakilan Rakyat, Dewan Perwakilan Rakyat Provinsi, dan Dewan Perwakilan Rakyat Daerah Kabupaten/Kota pasal 7 disebutkan syarat-syarat yang harus dipenuhi oleh setiap bakal calon yaitu: Telah berumur 21 Tahun (Dua Puluh Satu) tahun atau lebih. Bertakwa Kepada Tuhan Yang Maha Esa. Bertempat tinggal di wilayah Negara Kesatuan Republik Indonesia. Tidak pernah dihukum penjara atau kurungan berdasarkan putusan pengadilan yang sudah memiliki kekuatan hukum yang tetap, karena melakukan suatu tindak pidana kejahatan. Mempunyai pendidikan, kecakapan, keahlian dan keterampilan yang diperlukan. Berkelakuan baik, Sehat jasmani dan rohani, Berpendidikan paling rendah tamat sekolah menengah atas, madrasah aliyah, Sekolah Menengah Kejuruan, atau sekolah lain yang sederajat. Terdaftar sebagai pemilih. Bersedia bekerja penuh waktu.

Menurut pendapat Czudnowski dalam Fadillah Putra(2007:103) mengemukakan model yang digunakan partai politik dalam rekrutmen politik antara lain: Rekrutmen terbuka syarat dan prosedur untuk menampilkan seseorang tokoh dapat diketahui secara luas. Dalam hal ini partai politik berfungsi sebagai alat bagi elit politik yang berkualitas untuk mendapatkan dukungan masyarakat. Cara ini memberikan kesempatan bagi rakyat untuk melihat dan menilai kemampuan elit politiknya. Dengan demikian cara ini sangat kompetitif. Jika dihubungkan dengan paham demokrasi, maka cara ini juga berfungsi sebagai sarana rakyat mengontrol legitimasi politik para elit. Rekrutmen tertutup Berlawanan dengan cara rekrutmen terbuka. Dalam rekrutmen tertutup, syarat dan prosedur pencalonan tidak dapat secara bebas diketahui umum. Partai berkedudukan sebagai promotor elit yang berasal dari dalam tubuh partai itu sendiri. Cara ini menutup kemungkinan bagi anggota masyarakat untuk melihat dan menilai kemampuan elit yang ditampilkan. Dengan demikian cara ini kurang kompetitif. Hal ini menyebabkan demokrasi berfungsi sebagai sarana elit memperbaharui legitimasinya.

Sedangkan menurut Leijennar dan Niemaler (Pippa Norris, 1995:77) ada beberapa faktor yang dipertimbangkan oleh partai politik dalam menentukan calon legislatifnya yakni sebagai berikut: Karakteristik kemampuan yang meliputi: Pembicara yang baik, mempunyai keahlian khusus, memiliki semangat dan antusias tinggi serta mempunyai pengetahuan yang dalam terhadap isuisu politik, Karakteristik yang melekat meliputi: jenis kelamin, usia, etnis dan penampilan, Tingkat orientasi lokal meliputi: komitmen pada daerah pilihan, popularitas ditingkat lokal, dukungan massa partai politik dan organisasi kemasyarakatan. Agama, norma dan nilai meliputi: ketaatan beragama,kepedulian, dan kestabilan dalam kehidupan rumah tangga. Pengalaman politik meliputi: pengalaman politik dan pengalaman sebagai pekerja partai.

\section{METODE PENELITIAN}

Penelitian dilaksanakan pada Partai Perindo Kabupaten Sintang Provinsi Kalimantan Barat. Metode penelitian yang digunakan dalam penelitian ini adalah jenis penelitian kualitatif. Tujuan dari penelitian ini adalah mengukap fakta, keadaan, fenomena, variabel dan keadaan yang terjadi saat penelitian berjalan dan menyuguhkan apa adanya. Berdasarkan uraian diatas, maka penelitian ini mengunakan jenis penelitian deskriptif kualitatif. Menurut Nawawi (2007:33) metode penelitian deskriptif adalah penelitian yang dilakukan untuk mengetahui atau menggambarkan kenyataan dari kejadian yang diteliti atau penelitian yang dilakukan terhadap variablemandiri atau tunggal. Tujuan dari penelitian deskriptif kualitatif searah dengan rumusan masalah serta pertanyaan penelitian identifikasi masalah. Sehubungan dengan hal ini, maka berkenaan denganRekrutmen Calon Anggota DPRD Oleh DPD Partai Perindo Dalam Pemilihan Legislatif Di Kabupaten Sintang. Subjek penelitian adalah sumber utama data penelitian, yaitu yang memiliki data mengenai Variabel-variabel atau permasalahan-permalahan yang diteliti. Pada dasarnya subjek penelitian adalah yang akan 
dikenai kesimpulan hasil penelitian. Menurut Arikunto (2002:116) menyatakan subjek penelitian atau sasaran penelitian adalah satuan tertentu yang diperhitungkan sebagai subjek penelitian. Dikalangan peneliti kualitatif, istilah responden atau subjek penelitian disebut dengan informan, yaitu orang yang memberi informasi tentang data yang diinginkan peneliti berkaitan dengan penelitian yang sedang dilaksanakannya.

Adapun yang menjadi subjek dalam penelitian ini yang terdiri dari Ketua DPD Partai Perindo Kabupaten Sintang, Sekretaris DPDPartai Perindo Kabupaten Sintang, Caleg Partai Perindo Kabupaten Sintang. Teknik Sampling yang digunakan adalah Teknik Purposive Sampling yaitu salah satu teknik non random sampling dimana peneliti menentukan pengambilan sampel dengan cara menetapkan ciri-ciri khusus yang sesuai dengan tujuan penelitian sehingga diharapkan dapat menjawab permasalahan penelitian.

\section{HASIL PENELITIAN DAN PEMBAHASAN}

Partai Persatuan Indonesia atau biasa disingkat Partai Perindo adalah sebuah partai politik di Indonesia. Partai ini didirikan oleh Hary Tanoesoedibjo, pengusaha dan pemilik MNC Group, sebuah perusahaan yang bergerak dalam bidang media. Perindo di deklarasikan pada 7 Februari 2015 di Jakarta International Expo, Kemayoran, Jakarta. Pada acara deklarasi tersebut, dihadiri oleh beberapa petinggi Koalisi Merah Putih (KMP), seperti Ketua Umum Partai Golkar Aburizal Bakrie, Ketua Umum Partai Amanat Nasional Hatta Rajasa, Presiden Partai Keadilan Sejahtera Anis Matta, dan Ketua Umum Partai Persatuan Pembangunan Djan Faridz. Selain itu juga hadir Wiranto, Ketua Umum Hanura. Awalnya Perindo adalah ormas yang baru dideklarasikan pada 24 Februari 2013 di Istora Senayan, Jakarta.

VisiPartai Perindo adalah "Mewujudkan Indonesia yang berkemajuan, bersatu, adil, makmur, sejahtera, berdaulat, bermartabat dan berbudaya" sedangkan MisiPartai Perindo adalahsebagai berikut: Mewujudkan pemerintahan yang berkeadilan, yang menjunjung tinggi nilainilai hukum sesuai dengan UUD 1945. Mewujudkan pemerintahan yang bebas dari korupsi, kolusi dan nepotisme untuk Indonesia yang mandiri dan bermartabat. Mewujudkan Indonesia yang berdaulat, bermartabat dalam rangka menjaga keutuhan NKRI. Menciptakan masyarakat adil, makmur, dan sejahtera berdasarkan Pancasila dan UUD 1945 dalam wadah Negara Kesatuan Republik indonesia. Menegakkan hak dan kewajiban asasi manusia dan supremasi hukum yang susuai Pancasila dan UUD 1945 untuk mewujudkan keadilan dan kepastian hukum guna melindungi kehidupan rakyat, bangsa dan negara.
Mendorong tumbuhnya ekonomi nasional yang berkontribusi langsung pada kesejahteraan warga negara Indonesia. Organisasi itu sebagai struktur tata pembagian kerja dan struktur tata hubungan kerja antara sekelompok orang-orang pemegang posisi yang bekerjasama secara tertentu untuk bersama-sama mencapai tujuan yang tertentu. Struktur organisasi menunjukkan kerangka dan susunan perwujudan pola tetap hubungan diantara fungsi, bagian atau posisi maupun orang-orang yang menunjukkan tugas, wewenang dan tanggung jawab yang berbeda-beda dalam suatu organisasi.

Berikut ini kepegurusan Dewan Pimpinan Daerah Partai Perindo Kabupaten Sintang adalah sebagai berikut:

1. Ketua DPD Partai Perindo Kabupaten Sintang : Yulianus Asroni, S.E

2. Sekretaris DPD Partai Perindo Kabupaten Sintang : Prawito, S.Sos.,M.Si

3. Wakil Sekretaris Internal

:Tri Fitrianti

4.Wakil Sekr. Eksternal

: P. Da Costa Rae, SIP

5.Bendahara DPD Partai Perindo Kabupaten Sintang : Yosua

6. Wakil Bendahara DPD Partai Perindo Kab.

Sintang : Yohanes Buntet

7.Wakil Ketua Bidang Litbang dan IT

: Fera Carolina

8.Wakil Ketua Bidang Organisasi

: Pdt. Dr. Pieter Sobian, M.Th

9.Wakil Ketua Bidang Kader dan Saksi

: Drs. PE. Chunoi, M.Pd

10.Wakil Ketua Bidang Pemberdayaan Perempuan : Niken Puspita Sari, S.Sos

11.Wakil Ketua Bidang Pendidikan dan Kebudayaan : Warni Suryanti. M.Pd

12. Wakil Ketua Hukum dan Advokasi

: Santo Ambrosius, S.H

13.Wakil Ketua Bidang Sosial Ekonomi

: Edi Hermanto

14. Wakil Ketua Bidang Hubungan Antara lembaga :Kristiana Liliyanti, S.Sos

\section{Pencalonan}

Rekrutmen Calon Anggota DPRD Oleh DPD Partai Perindo Dalam Pemilihan Legislatif Di Kabupaten Sintang, dimana dalam tahapan ini mencakup interaksi antara elite partai di tingkat desa/kelurahan atau ranting partai dengan elite partai di tingkat atasnya atau anak cabang. Pencalonan yang telah dijaring. Tahapan ini meliputi interaksi antara elit tingkat anak cabang dan elite tingkat kabupaten/kota atau cabang/ daerah.Dijelaskan bahwa pencalonan mengacu Petunjuk Pelaksanaan (Juklak) dan Petunjuk Teknis (Juknis) yang telah dibuat oleh Dewan Pimpinan Pusat Partai Perindo. DPD Partai Perindo Kabupaten Sintang untuk menjalankan fungsinya dalam melakukan rekrutmen politik. Melakukan rekrutmen politik dengan cara memasang iklan 
terbuka dengan berbagai media layaknya sebuah perusahaan yang sedang membuka lowongan kerja cara ini digunakan oleh partai politik untuk menjaring Caleg dari luar partai.

DPD Partai Perindo Kabupaten Sintang terlebih dahulu membuka selebar-lebarnya bagi masyarakat yang ingin mengabdi dan berjuang untuk tanah air khususnya jalur Legislatif, dengan harapan masyakat yang diajak oleh Perindo adalah masyarakat yang dibutuhkan oleh Bangsa dan Negara.

Adapun tahap Pencalonan penulis sampaikan pada tabel berikut ini:

\begin{tabular}{|c|c|c|}
\hline Nomor & Tahapan & Keterangan \\
\hline 1 & 2 & 3 \\
\hline 1 & Pengambilan Formulir & 1 februari - 2 Maret 2018 \\
\hline 2 & $\begin{array}{l}\text { Pengambilan Formulir beserta syarat } \\
\text { Pendaftaran Calon Legislatif }\end{array}$ & 2 Februari - 30 Maret 2018 \\
\hline 3 & $\begin{array}{l}\text { Penelitian Administrasi dan Kelengkapan } \\
\text { Bacaleg }\end{array}$ & 2 Februari - 30 Maret2018 \\
\hline 4 & $\begin{array}{l}\text { Pengumuman hasil administrasi dan } \\
\text { Kelayakan Bacaleg }\end{array}$ & $1-7$ April 2018 \\
\hline 5 & Uji Publik/Fit Profer Tes/Interview & 8 - 30 April 2018 \\
\hline 6 & Penyusunan Daftar Caleg Perindo & 1 - 30 Mei 2018 \\
\hline 7 & $\begin{array}{l}\text { Pengumuman Caleg Perindo di Media } \\
\text { Massa }\end{array}$ & 15 Juni 2018 \\
\hline
\end{tabular}

Adapun dokumen yang dibutuhkan untuk pendaftaran secara online penulis adalah File KTP:File scan KTP dalam format jpg, png atau PDF. (max.2 MB), File Foto: File scan foto $1 / 2$ badan ukuran $4 \times 6$ dalam format Jpg,Png atau PDF (max 2 MB), File Ijasah :File Scan

\section{Seleksi}

Proses seleksi merupakan serangkaian tahap atau langkah dengan menggunakan berbagai macam teknik atau metode seleksi yang harus dilalui oleh para calon peserta seleksi untuk memilih beberapa orang yang sesuai dengan kebutuhan Partai Perindo.Seleksi PencalegkanPartai Perindo sebagai suatu proses pemilihan beberapa orang dari pendidikan tertinggi /terakhir dalam format Jpg,Png atau PDF (Max 2 MB), Dokumen akte lahir, Dokumen Kartu keluarga, Dokumen Menikah/surat nikah bagi yang sudah menikah, Informasi Email, Nomor Telpon Caleg.

sekumpulan orang-orang dengan kualifikasi tertentu yang dibutuhkan sesuai dengan persyaratan Calon Legislatif. Berikut ini data tentang jumlah caleg Partai Perindo Kabupaten Sintang yang telah lolos seleksi adalah sebagai berikut:

\begin{tabular}{|c|l|c|}
\hline Nomor & \multicolumn{1}{|c|}{ Daerah Pemilihan } & Jumlah \\
\hline 1 & Dapil 1: Kecamatan Sintang & 7 Orang \\
\hline 2 & $\begin{array}{l}\text { Dapil 2: Kecamatan Binjai, Ketungau Hilir, Ketungau } \\
\text { Tengah, Ketungau Hulu }\end{array}$ & 8 Orang \\
\hline 3 & Dapil 3: Kecamatan Kelam Permai, Tebelian, Dedai & 8 Orang \\
\hline 4 & Dapil 4 : Kecamatan Kayan Hulu, Kayan Hilir & 5 Orang \\
\hline 5 & Dapil 5: Kecamatan Serawai, Ambalau & 4 Orang \\
\hline 6 & Dapil 6: Kecamatan Sepauk, Tempunak & 7 Orang \\
\hline
\end{tabular}

Berdasarkan pada tabel diatas bahwa Caleg Partai Perindo yang lolos seleksi dan ditetapkan sebagai Calon Anggota DPRD Kabupaten Sintang masa bakti 2019-2024 adalah sebanyak 40 orang yang terdiri dari laki-laki 23 Orang sedangkan perempuan berjumlah 17 orang. 


\section{Penyaringan}

Tata Cara Penentuan Daftar penyaringan Calon Anggota Legislatif Partai Perindodilakukan penilaian terhadap kader bakal calon anggota Legislatif meliputi aspek: a.Aspek Pengabdian adalah rekam jejak seorang kader dalam Partai Perindoyang meliputi partisipasi seorang kader di saat menjabat sebagai pengurus partai, pengurus organisasi sayap, pengurus badan dan lembaga, pengurus Ormas yang didirikan maupun yang mendirikan. b. Aspek Elektabilitas adalah peluang keterpilihan seorang kader pada suatu daerah pemilihan dilihat dari sisi basis dukungan massa. c. Aspek Penugasan Fungsionaris; (laporan kegiatan penugasan), adalah suatu bentuk penugasan yang diberikan kepada setiap Fungsionaris partai setelah kader yang bersangkutan mengikuti orientasi fungsionaris. Penugasan fungsionaris dimaksudkan agar tiap-tiap fungsionaris Partai Perindomemberikan kontribusi aktif dalam konsolidasi partai (vertikal dan horizontal) memaksimalkan pelaksanaan kaderisasi partai, serta mendorong pelaksanaan program karyakekaryaan di daerah penugasan masing-masing. d. Aspek Pendidikan adalah pengalaman pendidikan seorang kader meliputi pendidikan formal, non formal dan pendidikan kepartaian.

Disamping itu diperkuat dengan syarat Penyaringan: a) Memiliki kompetensi yang memadai untuk menjalankan tugas-tugas sebagai anggota legislatif; b) Memiliki pengabdian dan rekam jejak yang baik selama aktif di Partai Perindo; c) Memiliki prestasi, dedikasi, disiplin, loyalitas dan tidak tercela; dan d) Memenuhi ketentuan yang disyaratkan oleh Undang-Undang.

Berikut ini nama yang lolos Rekrutmen Calon Anggota DPRD Oleh DPD Partai Perindo Dalam Pemilihan Legislatif Di Kabupaten Sintang

\begin{tabular}{|c|c|c|}
\hline Nomor & Daerah Pemilihan & Nama Caleg \\
\hline 1 & Kecamatan Sintang & $\begin{array}{ll}\text { 1. } & \text { H. Sugianto, S.E } \\
\text { 2. } & \text { Iyes } \\
\text { 3. } & \text { Hesti } \\
\text { 4. } & \text { Kristina Seti } \\
\text { 5. } & \text { Jubir, Sri Mawarni } \\
\text { 6. } & \text { Tonisi Marsoit, S.Pd,M.Pd.K }\end{array}$ \\
\hline 2 & $\begin{array}{l}\text { Kecamatan Binjai, Ketungau Hilir, } \\
\text { Ketungau Tengah, Ketungau Hulu }\end{array}$ & $\begin{array}{ll}\text { 1. } & \text { Aleksander,SP } \\
\text { 2. } & \text { Gernan, S.Sos } \\
\text { 3. } & \text { Trivina Wismarti, A.Md } \\
\text { 4. } & \text { Erni Rospita Sari } \\
\text { 5. } & \text { Mikadius, S.Sos } \\
\text { 6. } & \text { Leju G } \\
\text { 7. } & \text { Mariani, S.Sos } \\
\text { 8. } & \text { Udi Hartono } \\
\end{array}$ \\
\hline 3 & $\begin{array}{l}\text { Kecamatan Kelam Permai, Tebelian, } \\
\text { Dedai }\end{array}$ & $\begin{array}{ll}\text { 1. } & \text { Prawito, S.Sos } \\
\text { 2. } & \text { Mamud, S.Sos } \\
\text { 3. } & \text { Maria Tamia } \\
\text { 4. } & \text { Meri Andani } \\
\text { 5. } & \text { Hamir Matius, S.Sos } \\
\text { 6. } & \text { Hesti Wati } \\
\text { 7. } & \text { Syahmadi } \\
\text { 8. } & \text { Eka Putra Dewangga, S.Pd }\end{array}$ \\
\hline 4 & Kecamatan Kayan Hulu, Kayan Hilir & $\begin{array}{ll}\text { 1. } & \text { Elkana, S.Pd } \\
\text { 2. } & \text { Ade Putra, S.H } \\
\text { 3. } & \text { Leberti Mega Sari } \\
\text { 4. } & \text { Elsie Melisa } \\
\text { 5. } & \text { Mika }\end{array}$ \\
\hline 5 & Kecamatan Serawai, Ambalau & $\begin{array}{ll}\text { 1. } & \text { S. Ahong, S.S.Sos } \\
\text { 2. } & \text { Tolek } \\
\text { 3. } & \text { Emilia Sagi Liarni, S.E } \\
\text { 4. } & \text { Elisabet } \\
\end{array}$ \\
\hline 6 & Kecamatan Sepauk, Tempunak & $\begin{array}{ll}\text { 1. } & \text { Vaulinus Lanan, S.Sos } \\
\text { 2. } & \text { Sofia Mariani } \\
\text { 3. } & \text { Lusiana } \\
\text { 4. } & \text { Laurensius Spilang } \\
\text { 5. } & \text { Agustinus, S.H } \\
\text { 6. } & \text { Herlina Aya } \\
\text { 7. } & \text { Adianto, S.ST }\end{array}$ \\
\hline
\end{tabular}




\section{KESIMPULAN DAN SARAN}

Pencalonan mengacu pada Petunjuk Pelaksanaan (Juklak) dan Petunjuk Teknis (Juknis) yang telah dibuat oleh Dewan Pimpinan Pusat Partai Perindo. Adapun tahapan Pencalonan adalah Pengambilan Formulir beserta syarat Pendaftaran Calon Legislatif, Penelitian Administrasi dan Kelengkapan Bacaleg, Pengumuman hasil administrasi dan Kelayakan Bacaleg, Uji Publik/ Fit Profer Tes/Interview, Penyusunan Daftar Caleg Perindo, Pengumuman Caleg Perindo di Media Massa. Seleksi oleh Dewan Pimpinan Daerah Partai Perindo dengan cara membentuk Tim Rekrutmen dan Seleksi Caleg. Rekrutmen Calon Anggota DPRD Kabupaten Sintang dari Partai Perindo masa bakti 2019-2024 yang lolos seleksi sebanyak 40 orang yang terdiri dari laki-laki 23 Orang sedangkan perempuan berjumlah 17 orang. Dewan Pimpinan Daerah Partai Perindo Kabupaten Sintang dalam Rekrutmen Calon Anggota DPRD dengan memperhatikan beberapa aspek memiliki kompetensi yang memadai untuk menjalankan tugas sebagai anggota legislatif; memiliki pengabdian dan rekam jejak yang baik selama aktif di Partai Perindo; memiliki prestasi, dedikasi, disiplin, loyalitas dan tidak tercela; dan memenuhi ketentuan yang disyaratkan oleh Undang-Undang. DPD Partai Perindo Kabupaten Sintang dalam Rekrutmen Calon Anggota DPRD dengan mempertimbangkan karakteristik kemampuan pembicara yang baik, mempunyai keahlian khusus, memiliki semangat dan antusias tinggi serta mempunyai pengetahuan yang dalam terhadap isu-isu politik. Komitmen pada Daerah Pemilihan, popularitas ditingkat lokal, dukungan massa partai politik dan organisasi kemasyarakatan, pengalaman politik dan pengalaman sebagai pekerja partai. Disarankan Rekrutmen Calon Anggota DPRD Partai Perindo Dalam Pemilihan Legislatif dimasa yang akan datang agar terus dimaksimalkan dengan membuka seluas-luas kepada masyarakat.Seleksi Calon
Anggota DPRD oleh Dewan Pimpinan Daerah Partai Perindo terutama Tim Rekrutmen dan Seleksi Caleg agar memperhatikan usulan dan saran dari masyarakat.Dewan Pimpinan Daerah Partai Perindo Kabupaten Sintang dalam Penyaringan Calon Anggota DPRD agar memprioritas Kader Partai Perindo.DPD Partai Perindo Kabupaten Sintang dalam Pemilihan Calon Anggota DPRD agar meningkatkan keterwakilan Kuota 30 Persen Perempuan sebagaimana amanah dalam Undang-undang Pemilu.

\section{DAFTAR PUSTAKA}

Fadillah Putra, 2007. Partai Politik dan kebijakan Publik.

Yogyakarta:Pustaka pelajar.

Haris, Samsudin, Praktek Parlementer Demokrasi Presidensial Indonesia, Yogyakarta: CV. Andi Offset, 2005.

Michael Rush dan Philip Althoff. 2007. Pengantar Sosiologi Politik, Penerbit: Rajawali, CI

Norris, Pippa. 2004. Electoral Enginering:Voting Rules Of Domestic Observers. Jurnal Of Democrcy.

Nawawi, Hadari. H. 2007. Metode Penelitian Bidang Sosial. Pontianak: Gadjah Mada University Press.

\section{PERATURAN PERUNDANG-UNDANGAN}

Undang-Undang Nomor 2 Tahun 2008 tentang Partai Politik.

Undang-Undang Nomor 8 Tahun 2012 tentang pemilihan umum anggota DPR, DPD dan DPRD.

Peraturan Komisi Pemilihan Umum Republik Indonesia Nomor 20 Tahun 2018 tentang Pencalonan Anggota Dewan Perwakilan Rakyat, Dewan Perwakilan Rakyat Provinsi, dan Dewan Perwakilan Rakyat Daerah Kabupaten/Kota. 